\title{
ATTRACTING STAKEHOLDERS TO THE IMPLEMENTATION OF THE PROGRAM FOR THE REGION'S SOCIO-ECONOMIC SECURITY
}

\author{
Hanna Kozachenko, D.Sc. in Economics, Professor \\ Olha Bondarevska, Ph.D. in Economics, Senior Lecturer \\ National University «Yuri Kondratyuk Poltava Polytechnic»
}

\author{
(C) Kozachenko H., 2019. \\ (C) Bondarevska O., 2019.
}

Стаття отримана редакиією 12.12 .2019 р.

The article was received by editorial board on 12.12.2019

Introduction. The program of the regional socio-economic security strengthening program implementation requires the joint efforts of various subjects ensuring security in the region. The region is a complex socio-economic system and the regional socio-economic security cannot be ensured only through administrative influence. Significantly greater results in the regional socio-economic security strengthening ensuring the can be achieved by combining the efforts of stakeholders and coordination of their interests.

Analysis of the latest research sources and publications. Over the past decades, the interest of managers to the issue of relationships with stakeholders has been constantly increasing, since it is difficult to find an effective mechanism for coordinating the interests of stakeholders. The concept of stakeholders is one of the most common one from a scientific and practical point of view. It is the basis of the "stakeholder theory of the company" as an independent direction of general and strategic management. In fact, the emergence of such an approach was a major breakthrough in the development of CSR business in front of society. In the monograph written by E. Freeman "Strategic Management: the Role of Stakeholders" (1984), which marked the beginning of this concept development, the author introduces a new term - "stakeholder". The theory and practice of the stakeholder approach is developed in the works by A. Carroll, who proposed using a matrix to personify the role of stakeholders. This matrix is made considering the levels of social responsibility, according to the principle of the CSR pyramid, which clearly demonstrates the multi-level responsibility of each interested party, combining it with expectations from cooperation. The matrix also enables to rank the importance of the stakeholders stuff and identify contradictions in their interests.

The problem of the stakeholder approach development is devoted to the scientific works by both foreign and domestic scientists. Among them such authors as A. Alekseeva, V. Apop, M. Berezina, A. Danylenko, V. Evtushenko, A. Carol, R. Kaplan, N. Kozlova, A. Kolot, N. Krasnokutska, N. Mitsenko, I. Mishchuk, T. Mostenska, A. Okhrimenko, L. Petrashko, M. Saprykina, A. Skull should be named. L. Konovalova, M. Korsakov and V. Yakimets consider the study of mutually beneficial expectations of stakeholders in the case of social partnership implementation in their work. At the same time, despite the large number of works about this issue, the topic of involving stakeholders in the program implementation to strengthen the regional socio-economic security has not been adequately studied and requires further scientific research.

Problem statement. The aim of the article is to study the advantages and risks of involving stakeholders in the program implementation to strengthen the regional socio-economic security.

Basic material and results. Stakeholder programs for the regional socio-economic security strengthening are individual officials, owners and heads of enterprises, organizations and institutions that are directly related to strengthening the socio-economic security of the region; or it is those of them that can affect the strengthening of its level, affect it using the available opportunities.

Attracting stakeholders at the regional level to strengthen the regional socio-economic security embodies the idea of the need to involve various subjects in the development and implementation of a program to strengthen the regional socio-economic security of the region. When developing a program to strengthen the regional socio-economic security, it enables to consider various opinions, local authorities can "hear" the opinion of community representatives of communities, the social sector, the media sector who are faced with certain problems, and the corresponding representatives of various groups are given the opportunity to express their opinions and be "heard" by the authorities. In implementing the program to 
strengthen the regional socio-economic security, the involvement of stakeholders implies not only that they can express their position, but also take specific actions [1].

Attracting various groups of stakeholders to solve the tasks of the program to strengthen the regional socio-economic security requires more time to coordinate actions and much more effort. The program to strengthen the regional socio-economic security implementation, which is based solely on the administrative efforts of local authorities without involving society, business and other interested parties, leads to a significant decrease in the program effectiveness. It is also possible if the implementation of its individual constituent parts is declarative in nature without real shifts in the social and economic spheres of the regional socio-economic security The benefits of attracting regional stakeholders to implement the program of the regional socio-economic security strengthening are given in Table. 1.

Table 1

The benefits of attracting stakeholders to meet the objectives of the program to strengthen the regional socio-economic security

\begin{tabular}{|l|l|}
\hline \multicolumn{1}{|c|}{ Advantages } & \multicolumn{1}{|c|}{ The content of advantages } \\
\hline $\begin{array}{l}\text { Development of territorial } \\
\text { communities }\end{array}$ & $\begin{array}{l}\text { Attracting different stakeholders within the same territorial } \\
\text { community can strengthen social relation in it, show unity of } \\
\text { interests and help to shape the community as a whole socio- } \\
\text { economic-territorial formation }\end{array}$ \\
\hline $\begin{array}{l}\text { Comprehensive coverage of regional } \\
\text { socio-economic security issues }\end{array}$ & $\begin{array}{l}\text { Involvement of different stakeholders allows a comprehensive } \\
\text { approach to solving various issues of social and economic } \\
\text { security (economic, social, criminal, administrative, etc.), } \\
\text { including ones through the legal use of different resources } \\
\text { belonging to different stakeholders. }\end{array}$ \\
\hline Resource Support & $\begin{array}{l}\text { Involvement of different stakeholders allows different types of } \\
\text { resources available to different stakeholders (material, financial, } \\
\text { administrative, informational, human, etc.) to solve common } \\
\text { tasks. }\end{array}$ \\
\hline $\begin{array}{l}\text { Information and communication } \\
\text { support }\end{array}$ & $\begin{array}{l}\text { Involvement of individual stakeholders enables to disseminate } \\
\text { information on the carried out activities and to attract sufficient } \\
\text { segments of the region population at least to inform them in order } \\
\text { to provide broad support for the activities }\end{array}$ \\
\hline $\begin{array}{l}\text { Dissemination of successful } \\
\text { experience } \\
\text { communities in Ukraine) }\end{array}$ & $\begin{array}{l}\text { Involvement of different stakeholders enables to accumulate and, } \\
\text { if necessary, disseminate positive experience in implementing } \\
\text { measures to strengthen the regional socio-economic security of } \\
\text { the region }\end{array}$ \\
\hline $\begin{array}{l}\text { Display support } \\
\text { (n) }\end{array}$ & $\begin{array}{l}\text { Involvement of media representatives and media structures in } \\
\text { stakeholder groups enables to cover the issues of ensuring the } \\
\text { regional socio-economic security and to receive the necessary } \\
\text { support from different segments of the population, to inform the } \\
\text { public about the taken measures }\end{array}$ \\
\hline
\end{tabular}

The first of the advantages should be considered as the trend towards the territorial communities' creation and development, which today are pronounced in Ukraine. Over the past few years, Ukraine has been undergoing reform to consolidate administrative units and create territorial communities. Such a reform provides for a degree of independence for communities. And in such a situation, ensuring the regional socioeconomic security through the involvement of various stakeholders within the same territorial community is a way to strengthen relation within the same territorial community among representatives of various structures and population groups. In the future, it can have a significant positive impact on the functioning of the territorial communities as a whole, and the interests of the regional economy and regional governance various subjects coordination.

The advantage of involving stakeholders in the implementation of the program to strengthen the regional socio-economic security should be considered the possibility of a comprehensive solution to the issues of strengthening the regional socio-economic security, when each of the stakeholders participates in the implementation of the program to strengthen the regional socio-economic security based on the opportunities that it has. For example:

- representatives of media structures can inform the public about the objectives of the program, provide feedback;

- representatives of scientific educational institutions can form the scientific basis of the program tasks and carry out outreach among young people; 
- business representatives are able to find resources of various kinds to solve the program tasks.

The combination of various resources (not only material) that are available to various regional stakeholders enables to provide for the most comprehensive approach to the fulfillment of the program objectives to strengthen the regional socio-economic security of the region.

Regional stakeholders have different resources: material, financial, administrative, informational, and human [2]. And for the successful implementation of the developed program to strengthen the regional socio-economic security, it is necessary to attract all types of resources and combine them. Special attention should be paid to the information and communication support that the media, media resources and educational institutions can provide. It should be emphasized that the regional socio-economic security strengthening is a task not only for regional authorities. This question is important for all stakeholders. Therefore, it is important to inform about media support and actions as for the regional socio-economic security strengthening, including program implementation.

Finally, the wide involvement of stakeholders within the reform of territorial communities in Ukraine helps to disseminate successful experience in implementing measures to strengthen the regional socioeconomic security. Also, it can not only ensure the regional socio-economic security strengthening in a particular region, but it also creates a positive effect for neighboring regions. It is possible if such an experience has a real and tangible effect.

Attracting stakeholders to solve the tasks of the program to strengthen the regional socio-economic security has not only advantages, but also carries certain risks that need to be identified, prevented. In case of their occurrence, it should be reacted betimes. The risks of involving stakeholders in fulfilling the program tasks to strengthen the regional socio-economic security are presented in table. 2.

Table 2

Risks of attracting stakeholders to fulfill the tasks of the program to strengthen the regional socio-economic security

\begin{tabular}{|c|c|}
\hline Risk & Content of risk \\
\hline $\begin{array}{l}\text { Antagonistic } \quad \text { relationships } \\
\text { among individual stakeholders }\end{array}$ & $\begin{array}{l}\text { Conflict interpersonal relationships among individual stakeholders } \\
\text { through conflicts of interest or interpersonal relationships }\end{array}$ \\
\hline $\begin{array}{l}\text { Fundamental conflict of } \\
\text { interests is unresolved }\end{array}$ & $\begin{array}{l}\text { The existence of a fundamental conflict of interests among individual } \\
\text { stakeholders that cannot be resolved (the conflict is described by a win- } \\
\text { lose positional game) and therefore makes it impossible for them to } \\
\text { cooperate even to solve the common task of strengthening the regional } \\
\text { socio-economic security }\end{array}$ \\
\hline $\begin{array}{l}\text { Lack of principled stakeholder } \\
\text { interest in addressing the } \\
\text { region socio-economic } \\
\text { security challenges }\end{array}$ & $\begin{array}{l}\text { The stakeholder has no interest in addressing the regional socio- } \\
\text { economic security challenges. He is not interested in the region } \\
\text { development, guided only by self-interests that are not related to the } \\
\text { region interests }\end{array}$ \\
\hline Time consuming & $\begin{array}{l}\text { Stakeholder involvement in the implementation of a program to } \\
\text { strengthen the regional socio-economic security and coordinate their } \\
\text { actions requires such a considerable amount of time that it becomes } \\
\text { unjustified or ineffective in terms of enhancing the regional socio- } \\
\text { economic security in the context of the changing environmental } \\
\text { environment. }\end{array}$ \\
\hline $\begin{array}{l}\text { Regulatory restrictions at the } \\
\text { level of national regulations }\end{array}$ & $\begin{array}{l}\text { The implementation of some planned measures to strengthen the regional } \\
\text { socio-economic security is directly prohibited by national regulations, or } \\
\text { requires additional permitting procedures }\end{array}$ \\
\hline $\begin{array}{l}\text { Limited stakeholder capacity } \\
\text { or competence }\end{array}$ & $\begin{array}{l}\text { The competence of the individual stakeholder to carry out specific } \\
\text { planned measures to strengthen the regional socio-economic security is } \\
\text { limited and insufficient to implement such measures. }\end{array}$ \\
\hline $\begin{array}{l}\text { Disclosure of confidential } \\
\text { information on the regional } \\
\text { socio-economic security }\end{array}$ & $\begin{array}{l}\text { Leakage of confidential information on the state of regional socio- } \\
\text { economic security and formation of a negative public reaction to the } \\
\text { taken actions }\end{array}$ \\
\hline $\begin{array}{l}\text { Efforts of individual } \\
\text { stakeholders to use } \\
\text { participation in enhancing the } \\
\text { regional socio-economic } \\
\text { security to meet their own } \\
\text { goals. Opportunistic behavior }\end{array}$ & $\begin{array}{l}\text { Conscious actions of individual stakeholders to respect and protect their } \\
\text { interests against the interests of other regional stakeholders and contrary } \\
\text { to the task of ensuring the regional socio-economic security, which is } \\
\text { possible due to the availability of information on the activities } \\
\text { undertaken by the stakeholders to ensure the regional socio-economic } \\
\text { security. }\end{array}$ \\
\hline
\end{tabular}


It is quite possible the emergence of antagonistic relations among individual stakeholders, which can be caused by both technical (working) and personal reasons, a conflict of business interests, the reluctance of stakeholders to provide resources through their limitations and so forth. Of course, if such stakeholders jointly participate in the implementation of the program to strengthen the regional socio-economic security it, it cannot but affect the procedure for its implementation. The manifestation of such antagonistic relations is an insoluble conflict of interests among individual stakeholders in the region. Of course, if there is such a conflict, then the general involvement of such stakeholders in projects or measures to strengthen the regional socio-economic security is doubtful. It does not exclude the possibility of such stakeholders' participation in various projects and activities of one program, but the intersection of their efforts and interests in the same project is a way to aggravate the conflict, and not to achieve the goals of the program to strengthen the regional socio-economic security.

A certain risk is the lack of real interest of stakeholders in solving the problems of the program for strengthening the regional socio-economic security: it involves not only the active and coordinating role of state authorities at the regional level, but also the wide involvement on a voluntary basis of various entities that affect the course of region socio-economic processes in the region to one degree or another.

The lack of stakeholders ' real interest in solving the program tasks to strengthen the regional socioeconomic security automatically leads to a decrease in the effectiveness of this program and its integrated nature. Due to the lack of stakeholders interest in real participation in the program, their contribution is significantly less, as well as the effect achieved from the implementation of the program is.

Table 3

Consequences of implementing the risks of attracting stakeholders to solve problems under the program to strengthen the regional socio-economic security

\begin{tabular}{|c|c|}
\hline Risk & \\
\hline $\begin{array}{lr}\text { Antagonistic } & \text { relationships } \\
\text { among } & \text { individual } \\
\text { stakeholders } & \\
\end{array}$ & \multirow{2}{*}{$\begin{array}{l}\text { The impossibility of cooperation between stakeholders within the } \\
\text { framework of the developed program to strengthen the socio-economic } \\
\text { security of the region. Complications and delays in program } \\
\text { implementation. Efforts of individual stakeholders to gain a winning } \\
\text { position or additional resources at the expense of other stakeholders } \\
\text { during the program to strengthen the socio-economic security of the } \\
\text { region }\end{array}$} \\
\hline $\begin{array}{l}\text { Fundamental conflict } \\
\text { interests is unresolved }\end{array}$ & \\
\hline $\begin{array}{l}\text { Lack of principled } \\
\text { stakeholder interest in } \\
\text { addressing the regional socio- } \\
\text { economic security challenges }\end{array}$ & $\begin{array}{l}\text { Lack of interest of individual stakeholders in the implementation of the } \\
\text { developed program to strengthen the regional socio-economic security, } \\
\text { which leads to emasculation of such program content, its declarative } \\
\text { formal nature, the absence of specific actions of individual stakeholders } \\
\text { and their desire to use their own resources }\end{array}$ \\
\hline suming & $\begin{array}{l}\text { acy of the planned measures to } \\
\text { ecurity due to their delay. the } \\
\text { anging state of regional socio- }\end{array}$ \\
\hline $\begin{array}{l}\text { ory restrictions } \\
\text { national regulati }\end{array}$ & \\
\hline $\begin{array}{l}\text { akeholder capacity } \\
\text { ence }\end{array}$ & $\begin{array}{l}\text { jects } \\
\text { g the }\end{array}$ \\
\hline $\begin{array}{l}\text { Disclosure of confidential } \\
\text { information on the regional } \\
\text { socio-economic security }\end{array}$ & siness climate of the region. Efforts of business re \\
\hline $\begin{array}{l}\text { Efforts of individual } \\
\text { stakeholders to use } \\
\text { participation in enhancing the } \\
\text { regional socio-economic } \\
\text { security to meet their own } \\
\text { goals. Opportunistic behavior }\end{array}$ & $\begin{array}{l}\text { The focus of the program actual content on the regional socio-economic } \\
\text { security strengthening to reach the interests of individual stakeholders and } \\
\text { the lack of sufficient attention to the interests of the public and society in } \\
\text { the region. Irrational spending of stakeholder resources within the } \\
\text { developed program }\end{array}$ \\
\hline
\end{tabular}


The risk of long time spent on the program to strengthen the regional socio-economic security implementation has a completely different character. Long time is due to several reasons:

the slow nature of public authorities activities in general;

the need to coordinate the efforts of various stakeholders in the program implementation;

resolving conflicts and misunderstandings among stakeholders;

the complex nature of the region as an object of managerial influence.

The implementation of these risks has a negative impact on the program objectives fulfillment to strengthen the regional socio-economic security. The consequences are presented in table. 3.

The regional socio-economic security strengthening must necessarily correlate with the existing regulatory framework, because any restrictions, prohibitions or simply the lack of permits at the level of national regulations can act as a significant deterrent to the implementation of measures to strengthen the regional socio-economic security. It is especially relevant for the interaction of regional authorities with state and non-communal property enterprises, the provision of certain preferences, and so forth.

Involving stakeholders in the implementation of a program to strengthen the regional socio-economic security may face such risks as limited opportunities or competencies of stakeholders. Each of the stakeholders has its own resources, capabilities and competencies for solving certain tasks of the program. And the lack of such resources negatively affects the ability of stakeholders to effectively participate in the program for strengthening the regional socio-economic security implementation. Even if the stakeholder wants to take part in the implementation of the program, it is precisely the lack of resources and / or competencies and capabilities that can become a serious obstacle.

There is a certain risk of the disclosure of confidential information if stakeholders are involved in the implementation of the program to strengthen the regional socio-economic security: participation of stakeholders in coordination activities, involvement in the implementation of certain measures certainly lead to familiarization of stakeholders with confidential information. Thus, in this case, the risk of its disclosure exists. Such a risk is directly related to the subsequent risk - an attempt by individual stakeholders to use participation in the implementation of the program to strengthen the enterprise socio-economic security to achieve their own goals. Also, their opportunistic behavior is possible, even to the detriment of the interests of such a program.

Opportunistic behavior is one of the important concepts in the concepts of institutionalism and neoinstitutionalism and is traditionally regarded as following one's own interests. This definition is not limited to moral judgments [3, p. 43]. Opportunism can manifest itself not only in the desire to satisfy one's own interests, but also in misleading, distorting or hiding the truth [4, p. 98]. It is opportunistic behavior that leads to additional threats and risks for participants in economic relations. And therefore, the opportunistic behavior of stakeholders who have confidential information; they can damage the program to strengthen the regional socio-economic security. The risks of involving stakeholders in the implementation of the program to strengthen the regional socio-economic security are identified, and the risks of the consequences of the program require attention to the proactive neutralization of risks and their elimination. The developed principal ways of overcoming the risks of attracting stakeholders to solve the program problems for strengthening the regional socio-economic security are presented in table. 4.

The principal ways of overcoming the risks of attracting stakeholders to solve the tasks of the program for the regional socio-economic security strengthening are not a guarantee that risks of possible consequences can be avoided [5]. However, the use of the provided ways avoids individual risks even before they arise, outstrips and prevents the occurrence of such risks, and increases the probability of the program effective implementation to strengthen the regional socio-economic security.

Conclusions. Attracting stakeholders at the regional level to strengthen the regional socio-economic security enables to consider various opinions, local authorities can "hear" the opinion of community representatives of communities, the social sector, the media sector and the corresponding representatives of various groups. In implementing the program to strengthen the regional socio-economic security, the involvement of stakeholders implies not only that they can express their position, but also take specific actions. 
Table 4

The principal ways to overcome the risks of attracting stakeholders to solve the problems of the program for strengthening the regional socio-economic security

\begin{tabular}{|c|c|}
\hline Risk & $\begin{array}{l}\text { Principal ways of overcoming risk } \\
\end{array}$ \\
\hline $\begin{array}{l}\text { Antagonistic relationships } \\
\text { among individual stakeholders }\end{array}$ & \multirow{2}{*}{$\begin{array}{l}\text { Only those stakeholders bringing in the program to strengthen the } \\
\text { regional socio-economic security, who have no conflicts and } \\
\text { antagonistic relations in advance }\end{array}$} \\
\hline $\begin{array}{l}\text { Fundamental conflict of interests } \\
\text { is unresolved }\end{array}$ & \\
\hline $\begin{array}{l}\text { Lack of principled stakeholder } \\
\text { interest in addressing the } \\
\text { regional socio-economic security } \\
\text { challenges }\end{array}$ & $\begin{array}{l}\text { Search for motives and incentives (material, administrative, social, } \\
\text { personal, etc.) to involve the stakeholder in solving the problems of } \\
\text { regional socio-economic security. A clear understanding of such } \\
\text { motives for a particular range of stakeholders }\end{array}$ \\
\hline uming & $\begin{array}{l}\text { Use of project management techniques and techniques that minimize } \\
\text { time spent, provided the goals are met. } \\
\text { Preliminary maximum reconciliation of interests of all } \\
\text { performers to prevent the negative impact of conflict of interest }\end{array}$ \\
\hline $\begin{array}{l}y \text { restrictions at the } \\
\text { ational regulations }\end{array}$ & $\begin{array}{l}\text { rding its } \\
\text { nentation }\end{array}$ \\
\hline $\begin{array}{l}\text { Limited stakeholder capacity or } \\
\text { competence }\end{array}$ & $\begin{array}{l}\text { tentions of } \\
\text { ibility for }\end{array}$ \\
\hline $\begin{array}{l}\text { Disclosure of confidential } \\
\text { information on the socio- } \\
\text { economic security of the region }\end{array}$ & $\begin{array}{l}\text { g non-disclosure agreements with a clear statement } \\
\text { or breach of such agreements }\end{array}$ \\
\hline $\begin{array}{l}\text { Efforts of individual } \\
\text { stakeholders to use participation } \\
\text { in enhancing the regional socio- } \\
\text { economic security to meet their } \\
\text { own goals. Opportunistic } \\
\text { behavior }\end{array}$ & $\begin{array}{l}\text { Public monitoring involving a wide range of individuals, including } \\
\text { representatives of government, non-governmental organizations, the } \\
\text { media, to prevent and disclose the facts of opportunistic behavior by } \\
\text { stakeholders. } \\
\text { Signing special stakeholder agreements in case of a conflict of interest, } \\
\text { warning other program executors of such a conflict, and ways to } \\
\text { resolve it. } \\
\text { Making ckear the conditions for withdrawal of legal entities and } \\
\text { individuals }\end{array}$ \\
\hline
\end{tabular}

The advantage of involving stakeholders in the implementation of the program to strengthen the regional socio-economic security should be considered the possibility of a comprehensive solution to the issues of strengthening the regional socio-economic security, when each of the stakeholders participates in the implementation of the program to strengthen the regional socio-economic security based on the opportunities that it has.

Regional development strategies should become effective development plans, and it is necessary to attract a wider range of stakeholders: public organizations, regional development agencies, entrepreneurs and other interested parties. The more people are involved in developing this strategy, the more they feel responsible for it, and the more effectively it is implemented.

\section{REFERENCES}

1. Ammari A.O. Klasyfikatsiia steikkholderiv na osnovi vzaiemnykh ochikuvan // Aktualni problemy ekonomiky №8(134), 2012. - 150-155 s.

2. $\quad$ Lahuta Ya.M. Steikkholderskyi pidkhid v korporatyvnii sotsialnii vidpovidalnosti kompanii // Naukovyi visnyk Mizhnarodnoho humanitarnoho universytetu №25-1, 2017. - 130-133 s.

3. Vartsaba V.I. Upravlinnia rehionalnym rozvytkom: teoriia i praktyka harmonizatsii tsilei ta interesiv vlady, nauky, biznesu: monohrafiia. Ivano-Frankivsk, 2015. $486 \mathrm{~s}$.

4. Viliamson O. Ekonomichni instytutsii kapitalizmu. Firmy, marketynh, ukladannia kontraktiv / per. z anhl. K. : ArtEk, 2001. 457 s. 
5. Zhyvytskyi D. Rehiony povynni zaluchyty yakomoha bilshe steikkholderiv do pidhotovky stratehii rozvytku. - Elektronnyi resurs. Rezhym dostupu: https://www.kmu.gov.ua/news/regioni-povinnizaluchiti-yakomoga-bilshe-stejkholderiv-do-pidgotovki-strategij-rozvitku-dmitro-zhivickij

6. Stakeholder Judgments of Value: Advancing Stakeholder / [L.Lankoski, N. Stmith, L. Van Wassenhove] // Theory through Prospect Theory, INSEAD, 2011 [Electronic resource]. - Available at: http://www.hbs.edu/faculty/conferences/2013-sustainabilityandcorporation/Documents/Stakeholder_judgments of value 0513FV.pdf

UDC 65.012.65:332.12

Козаченко Ганна Володимирівна, доктор економічних наук, професор. Бондаревська Ольга Миколаївна, кандидат економічних наук, старший викладач. Національний університет «Полтавська політехніка імені Юрія Кондратюка». Залучення стейкхолдерів до реалізації програми зміцнення соціально-економічної безпеки регіону. У статті визначено сутність поняття «стейкхолдери програми зміцнення соціально-економічної безпеки регіону». Розкрито переваги та ризики від залучення стейкхолдерів для вирішення завдань програми зміцнення соціально-економічної безпеки регіону. Обгрунтовано, що реалізація зазначених ризиків матиме негативний вплив на виконання завдань програми зміцнення соціально-економічної безпеки регіону. Авторами наведені наслідки реалізації ризиків залучення стейкхолдерів для вирішення завдань програми зміцнення соціально-економічної безпеки регіону. Запропоновані шляхи подолання ризиків залучення стейкхолдерів для вирішення завдань програми зміцнення соціально-економічної безпеки регіону.

Ключові слова: стейкхолдери, регіон, безпека, програма, соціально-економічна безпека регіону, переваги, ризики, регіональна програма, регіональний розвиток.

\section{UDC 65.012.65:332.12}

Kozachenko Hanna, D.Sc. (Economics), Professor. Bondarevska Olha, Phd (Economics), Senior Lecturer. National University "Yuri Kondratyuk Poltava Polytechnic". Attracting Stakeholders to the Implementation of the Program for the Region's Socio-Economic Security. The article defines the essence of the concept of "stakeholders in the program of strengthening the socio-economic security of the region". The benefits and risks of attracting stakeholders to meet the objectives of the program to strengthen the regional socio-economic security are identified. It is justified that the implementation of these risks has a negative impact on the program objectives fulfillment to strengthen the regional socio-economic security. Consequences of implementing the risks of attracting stakeholders to solve problems under the program to strengthen the regional socio-economic security are explained. The principal ways to overcome the risks of attracting stakeholders to solve the problems of the program for strengthening the regional socio-economic security are suggested.

Keywords: stakeholders, region, security, program, socio-economic security of the region, benefits, risks, regional development program.

\section{UDC 65.012.65:332.12}

Козаченко Анна Владимировна, доктор экономических наук, профессор. Бондаревская Ольга Николаевна, кандидат экономических наук, старший преподаватель. Национальный университет «Полтавская политехника имени Юрия Кондратюка». Привлечение стейкхолдеров к реализации программы укрепления социальноэкономической безопасности региона. В статье определена сущность понятия «стейкхолдеры программы укрепления социально-экономической безопасности региона». Раскрыто преимущества и риски от привлечения стейкхолдеров для решения задач программы укрепления социальноэкономической безопасности региона. Обосновано, что реализация указанных рисков будет иметь негативное влияние на выполнение задач программы укрепления социально-экономической безопасности региона. Авторами приведены последствия реализации рисков привлечения стейкхолдеров для решения задач программы укрепления социально-экономической безопасности региона. Предложены пути преодоления рисков привлечения стейкхолдеров для решения задач программы укрепления социально-экономической безопасности региона.

Ключевые слова: стейкхолдеры, регион, безопасность, программа, социально-экономическая безопасность региона, преимущества, риски, региональная программа развития. 